\title{
Supplementation with a mixture of whole rice bran and crude glycerin on metabolic responses and performance of primiparous beef cows
}

\author{
Juan Manuel Clariget ${ }^{1}$, Lorena Román ${ }^{1}$, Mauricio Karlen ${ }^{1}$, Andrea Álvarez-Oxiley ${ }^{1}$, Carlos \\ López-Mazz' ${ }^{1}$, Raquel Pérez-Clariget ${ }^{1}$
}

1 Universidad de la República, Facultad de Agronomía, Montevideo, Uruguay.

\begin{abstract}
This study investigated the effect of a supplement containing whole rice bran and crude glycerin for 21 days before mating on metabolic, productive, and reproductive responses of 28 primiparous suckling beef cows. Cows were randomly assigned to a control group $(\mathrm{CON}, \mathrm{n}=14)$, grazing on grasslands, and a supplemented group $(\mathrm{SUP}, \mathrm{n}=14)$, grazing on grasslands and supplemented daily individually with $1 \mathrm{~kg}$ dry matter (DM) of whole rice bran $+550 \mathrm{~mL}$ crude glycerin (224 g kg-1 DM of methanol) per cow. After 33 days of natural mating, cows that had not expressed estrus were subjected to a fixed-time artificial insemination protocol. Ten days after the insemination program, bulls were reintroduced for 21 days. Supplementation increased milk yield (SUP: $5.7 \pm 0.2$ vs. CON: $5.0 \pm 0.2 \mathrm{~kg} \mathrm{~d}^{-1}$ ), milk protein content (SUP: $3.1 \pm 0.2$ vs. CON: $2.8 \pm 0.2 \%$ ), and body weight of cow (SUP: $379 \pm 2$ vs. CON: $373 \pm 2 \mathrm{~kg}$ ) and calf (SUP: $150 \pm 2 \mathrm{vs.} \mathrm{CON:} 142 \pm 2 \mathrm{~kg}$ ). Supplementation improved the energy balance, increased plasma concentrations of cholesterol (SUP: $223.2 \pm 6.4$ vs. CON: $202.1 \pm 6.4 \mathrm{mg} \mathrm{dL}^{-1}$ ) and glucose (SUP: $72.0 \pm 1.2 \mathrm{vs}$. CON: $68.6 \pm 1.2 \mathrm{mg} \mathrm{dL}^{-1}$ ), and reduced non-esterified fatty acids (SUP: $0.45 \pm 0.02$ vs. CON: $0.56 \pm 0.02 \mathrm{mmol} \mathrm{L}^{-1}$ ). The percentage of cows on superficial anestrous after supplementation was greater in SUP than in CON group (57 vs. $21 \%$, respectively); however, no difference in final pregnancy rate was found (SUP: 79 vs. CON: 64\%). There was no evidence that the ingestion of crude glycerin with high content of methanol induced clinical or hepatic disorders. Supplementation of whole rice bran and crude glycerin is not toxic, and can improve the energy balance, reflecting in increase in milk yield and calf growth, with a slight effect on the reproductive activity.
\end{abstract}

Key Words: methanol, milk protein, shallow anestrus

\section{Introduction}

In extensive pastoral systems for meat production, primiparous suckled cows have the lowest reproductive efficiency and wean the lightest calves, which reduces the productivity of the herd (Bellows et al., 1982). The main cause of reproductive failure is the prolonged postpartum anestrus, induced by undernutrition (Short et al., 1990; Hess et al., 2005) and suckling (Williams, 1990). The nutrient supply of grasslands during the winter is insufficient to meet the requirements of the growing fetus in the last third of the pregnancy period, causing a negative energy balance that continues during early postpartum due to the demand for milk production (Bell, 1995; Astessiano et al., 2013). The negative energy balance is evidenced by a decrease in body condition score (BCS) and endocrine changes, such as an increase in non-esterified fatty acids

Received April 17, 2015 and accepted November 18, 2015.

Corresponding author: jmclariget@hotmail.com

http://dx.doi.org/10.1590/S1806-92902016000100003

Copyright (C) 2016 Sociedade Brasileira de Zootecnia. This is an Open Access article distributed under the terms of the Creative Commons Attribution License (http://creativecommons.org/licenses/by/4.0/), which permits unrestricted use, distribution, and reproduction in any medium, provided the original work is properly cited.
(NEFA) and a decrease in glucose and insulin, which have a negative impact on follicle growth and ovulation (Wiltbank, 1970; Mulliniks et al., 2011).

Postpartum supplementation can overcome, at least partially, pre-partum undernutrition (Perry et al., 1991; Ciccioli et al., 2003). Short-term supplementations before or during the mating period, with or without association with temporary weaning, are alternatives to increase pregnancy rates in cows with sub-optimal BCS (Pérez-Clariget et al., 2007; Soca et al., 2013). The supplement most frequently used in these studies has been whole rice bran, an energy nutrient with 130-180 $\mathrm{g} \mathrm{kg}^{-1}$ of crude protein (CP) (Wang et al., 2012). On the other hand, the biodiesel industry has increased the availability of crude glycerin that can be used in ruminant nutrition (Donkin, 2008). The main component of crude glycerin is glycerol, a powerful gluconeogenic alcohol (Alexander et al., 2010). However, the main disadvantage of crude glycerin is that its methanol content can impair liver function (Schröder and Südekum, 1999).

The hypothesis of this study was that short-term supplementation before mating with whole rice bran and crude glycerin with high content of methanol improves the energy balance and the performance of primiparous 
beef cows grazing grasslands without impairing liver function. The aim of this study was to evaluate the effect of supplementation for 21 day before mating with whole rice bran and crude glycerin with high level of methanol on body weight, body condition, milk production, hormonal and metabolic profiles, ovarian activity, pregnancy rate, and liver function in primiparous beef cows and the growth of their calves grazing grasslands.

\section{Material and Methods}

The experiment was conducted in an experimental station in eastern Uruguay $\left(32^{\circ} \mathrm{S}, 54^{\circ} \mathrm{W}\right)$ according to the experimental procedures approved by the Animal Experimental Committee of Universidad de la República (UdelaR).

Twenty-eight pregnant Hereford, Aberdeen Angus, and crossbred heifers ( $\mathrm{n}=4,10,14$; respectively) with $424 \pm 7 \mathrm{~kg}$ of body weight (BW) and $5.1 \pm 0.1$ units of BCS (1-8 scale: 1 = very thin, 8 = very fat; Vizcarra et al., 1986) were monitored from $16 \pm 1$ weeks pre-partum (early winter) until $47 \pm 1$ days post-partum (DPP), when the supplementation period began.

At the start of supplementation (day 0), BW and BCS were $371 \pm 7 \mathrm{~kg}$ and $3.8 \pm 0.1$, respectively. All the cows were suckling and in deep anestrus confirmed by the absence of a corpus luteum and the presence of follicles $<9 \mathrm{~mm}$ in diameter in the ovaries in two ultrasound studies nine days apart (Wiltbank et al., 2002).

Cows were paired based on DPP, BCS, BW, genotype (crossbred vs. pure) and sex of the calf. One member of each pair was randomly assigned to one of the following treatments: Control group $(\mathrm{CON}, \mathrm{n}=14)$ : grazing grasslands with no supplementation; and Supplemented group (SUP, $\mathrm{n}=14$ ): grazing grasslands and supplemented daily with $1 \mathrm{~kg} \mathrm{DM}$ of whole rice bran $+550 \mathrm{~mL}$ crude glycerin per cow for 21 days before the mating period. Whole rice bran and crude glycerin were premixed before individual supplementation. The metabolizable energy (ME) available in the supplement was $5.50 \mathrm{Mcal} \mathrm{d}^{-1}$, according to NRC (2001), and the CP content was $152 \mathrm{~g} \mathrm{~d}^{-1}$.

The chemical composition of the supplement components was evaluated before use (Table 1). Whole rice bran and herbage (Table 1) were evaluated for ether extract (EE; AOAC, 1990; N. 954.02), ash and CP (AOAC, 2007; N.942.05, N.984.13; respectively), and neutral and acid detergent fiber (NDF and ADF; Van Soest et al. 1991). The chemical composition of crude glycerin was evaluated for ash (AOCS, 1973; Ea 2-38), glycerol (AOCS, 2012; Ea 6-51), water (AOCS, 2009; Ea 8-58), fat (AOAC,
1980; 14.019), and CP (AOAC, 2007; N.984.13)], and the methanol content was determined by gas chromatography.

Calves were separated from their mothers for the first 14 days of the supplementation period while the cows were supplemented $(30 \mathrm{~min})$ to avoid interference, but they remained within visual, auditory, and olfactory contact. During the last 7 days of the supplementation period, calves of the CON and SUP groups with $61 \pm 1$ days of age were separated from their mothers and visual, auditory, and olfactory contact was prevented. During the temporary weaning, calves were kept separated in a small paddock and supplemented daily with $0.9 \mathrm{~kg}$ DM of alfalfa (Medicago sativa) hay bales per animal and $1.1 \mathrm{~kg}$ DM of early weaning ration (Bioración, Melo, Uruguay), containing $180 \mathrm{~g} \mathrm{~kg}^{-1}$ of $\mathrm{CP}$, per animal. Free access to water and shade was provided.

The first mating period lasted 33 days and started when cows were at $68 \pm 1$ DPP. The breeding soundness of the bulls was tested two months prior to the beginning of the breeding season. Estrus was detected 3 times per day $(7.00 \mathrm{~h}, 13.00 \mathrm{~h}$, and $19.00 \mathrm{~h})$; a cow was considered in estrus when it accepted being mounted by the bull. Cows that did not show estrus during this period were subjected to a fixed-time artificial insemination program. The protocol started on 101 \pm 1 DPP in the morning; an inert silicone intravaginal device containing $1 \mathrm{~g}$ of progesterone $\left(\mathrm{P}_{4}\right.$; DIB $^{\circledR}$, Syntex Laboratory, Buenos Aires, Argentina) was placed and $2 \mathrm{mg}$ of estradiol benzoate (Syntex Laboratory, Buenos Aires, Argentina) were injected. At the moment of $\mathrm{DIB}^{\circledR}$ withdrawal, in the morning of $108 \pm 1$ DPP, 500 mcg of cloprostenol (Ciclase $\mathrm{D}^{\circledR}$, Syntex Laboratory, Buenos Aires, Argentina) and 400 IU of equine chorionic gonadotrophin (Novormon ${ }^{\circledR}$, Sintex Laboratory, Buenos Aires, Argentina) were injected. On the following day, $1 \mathrm{mg}$ of estradiol benzoate was applied. All hormones were injected intramuscularly. The fixed-time artificial insemination was performed 52-56 $\mathrm{h}$ after removal of DIB $^{\circledR}$. This protocol of fixed-time artificial insemination

Table 1 - Chemical composition of whole rice bran, crude glycerin and herbage

\begin{tabular}{lccc}
\hline Item & Whole rice bran & Crude glycerin & Herbage \\
\hline Dry matter $\left(\mathrm{g} \mathrm{kg}^{-1}\right)$ & 874 & 894 & 418 \\
Ash $\left(\mathrm{g} \mathrm{kg}^{-1} \mathrm{DM}\right)$ & 85 & 95 & 112 \\
$\mathrm{CP}\left(\mathrm{g} \mathrm{kg}^{-1} \mathrm{DM}\right)$ & 149 & 7 & 84 \\
$\mathrm{NDF}\left(\mathrm{g} \mathrm{kg}^{-1} \mathrm{DM}\right)$ & 185 & - & 691 \\
$\mathrm{ADF}\left(\mathrm{g} \mathrm{kg}^{-1} \mathrm{DM}\right)$ & 61 & - & 320 \\
$\mathrm{EE}\left(\mathrm{g} \mathrm{kg}^{-1} \mathrm{DM}\right)$ & 171 & 323 & - \\
Glycerol $\left(\mathrm{g} \mathrm{kg}^{-1} \mathrm{DM}\right)$ & - & 348 & - \\
Methanol $\left(\mathrm{g} \mathrm{kg}^{-1} \mathrm{DM}\right)$ & - & 224 & - \\
\hline
\end{tabular}

DM - dry matter; CP - crude protein; NDF - neutral detergent fiber; ADF - acid detergent fiber; EE - ether extract. 
was the commercially recommended for suckled beef cows by the Laboratory Syntex S.A. (Buenos Aires, Argentina). Ten days after fixed-time artificial insemination, bulls were reintroduced with the cows for another 21 days.

All cows were managed as a single group during the entire experiment; they grazed together in the same pens of native grass, with forage availability greater than $2000 \mathrm{~kg} \mathrm{DM} \mathrm{ha}{ }^{-1}$ (minimum: $2121 \pm 515$, maximum: $6757 \pm 969 \mathrm{~kg} \mathrm{DM} \mathrm{ha}^{-1}$ ). Every month, cows were weighed and forage availability was determined by the double sampling method (Haydock and Shaw, 1975) using a $50 \mathrm{~cm}$ $\times 50 \mathrm{~cm}$ square, with five points scale and two replicates, cutting the forage at ground level, and herbage allowance was estimated. Forage height was determined as described previously (Soca et al., 2007). The green/dry mass ratio was estimated by visual assessment in the sampling square. These determinations were performed before animals were placed in the pens. Forage height was always greater than $15 \mathrm{~cm}$ (minimum: $16 \pm 2$, maximum: $26 \pm 4 \mathrm{~cm}$ ). Green/dry mass ratio decreased towards the end of winter and increased in spring from 48/52 in August to 84/16 in November. The predominant species were Axonopus sp, Paspalum dilatatum, Paspalum notatum, Paspalum quadrifarium, Stipa sp, Cynodon dactylon, Eryngium horridum, and Bothriochloa laguroides. The average herbage allowance during the entire experiment was $24 \mathrm{~kg}$ DM $(100 \mathrm{~kg} \mathrm{BW})^{-1}$ [(minimum: 16, maximum: $\left.37 \mathrm{~kg} \mathrm{DM}(100 \mathrm{~kg} \mathrm{BW})^{-1}\right]$. During supplementation, the cows remained in a paddock with a forage availability of $2121 \pm 515 \mathrm{~kg} \mathrm{DM} \mathrm{ha}{ }^{-1}$, $16 \pm 2 \mathrm{~cm}$ sward height, and $21 \mathrm{~kg}$ DM $(100 \mathrm{~kg} \mathrm{BW})^{-1}$ herbage allowance. Ten representative samples of herbage were taken and pooled for chemical composition analysis (Table 1).

Cow BCS was estimated by two trained technicians every 20 days from $16 \pm 1$ weeks of pre-partum until calving and every 14 days from calving until the end of the first mating period. The correlation between technicians was 0.91 , so the average of both values was used for the statistical analysis. Calf BW was recorded using an electronic scale (FX15, Iconix, Montevideo, Uruguay) at 47 (start of supplementation or day 0), 61 (beginning of temporary weaning with separation or day 14), 68 (end of temporary weaning with separation or day 21 ), and $82 \pm 1$ (day 35$)$ days of age and at definitive weaning (186 \pm 1 days of age or day 139).

Milk production was recorded on days $0,14,21$, and 35 from the beginning of supplementation, using a portable milking machine according to the method described by Mondragon et al. (1983). In the morning, after cows received their meal, calves were separated and the udder was emptied using $20 \mathrm{IU}$ of oxytocin i/m (Neurofisin, Lab Fatro, Uruguay). Seven hours later, cows were milked again using the same methodology. The total milk was individually weighed on an electronic scale and $24 \mathrm{~h}$ production was estimated. On days 0 and 14, individual samples were taken and milk composition (fat and protein) was determined in the laboratory (COLAVECO; Colonia, Uruguay) using infrared radiation absorption.

Weekly, from day 0 to day 49 , blood samples were collected by jugular venipuncture in Vacutainer ${ }^{\circledR}$ tubes with heparin (Becton, Dickinson and Company, Franklin Lakes, NJ, USA). Samples were centrifuged within the first hour of collection at $1530 \mathrm{~g}$ for $15 \mathrm{~min}$ and the plasma was collected and stored at $-20{ }^{\circ} \mathrm{C}$ until processing.

Cows were monitored daily by a veterinary during the supplementation period and one week after. During this period, attention was especially paid to any observable change in behavior, eye alterations or impaired vision, changes in the respiratory rate and depth frequency of the chewing motion, or signs of hypoesthesia (Coppock and Christian, 2012). To evaluate possible hepatic damage due to ingestion of the methanol contained in the crude glycerin, another blood sample was collected at day 110 after the beginning of the supplementation using tubes without anticoagulant. Samples were immediately centrifuged, and the serum was frozen and transported to the laboratory. Liver function was studied through the concentrations of total protein, albumin, globulin, total bilirubin, aspartate amino transferase (ASAT), alkaline phosphatase (ALP), and gamma-glutamyl transpeptidase (GGT).

From day -9 to 49 , the ovaries were examined weekly by transrectal ultrasonography using a linear bimodal (5.0 to $7.5 \mathrm{MHz}$ ) transducer (Ambivision, Digital Notebook B mode, Model AV-3018V, Manufacturer AMBISEA Technology Corp., Ltd., China). Ovarian follicles and corpus luteum were identified according to the criteria described by Griffin and Ginther (1992). The size of the largest follicle was used to classify the type of anestrus. Cows with follicles $>8 \mathrm{~mm}$ in diameter in two or more occasions without corpus luteum were considered in shallow anestrus and those with follicles $\leq 8 \mathrm{~mm}$ in diameter without corpus luteum were considered in deep anestrus. Resumption of ovarian activity was monitored by the concentration of progesterone $\left(\mathrm{P}_{4}\right)$, considering that cyclicity was reinitiated if a $\mathrm{P}_{4}$ concentration $\geq 1 \mathrm{ng} \mathrm{mL}$ was found in two successive samples with one week interval (Meikle et al., 2004) and a corpus luteum was identified in two ultrasound scans with a 7-day interval. Pregnancy was diagnosed by transrectal ultrasonography at 46 and 66 days after fixed-time artificial insemination. 
Progesterone concentration was determined in all cows in samples collected on days 35,42 , and 49 from the beginning of supplementation. If a corpus luteum was observed by ultrasonography on any of those days, blood samples collected two weeks before and to two weeks after were also analyzed. The $\mathrm{P}_{4}$ concentration was determined by solid phase radioimmunoassay using commercial kits (DPC, Diagnostic Products Co. Los Angeles, CA, USA). All samples were analyzed in one assay, with the standard curve and controls in duplicate and the samples in single. The assay sensitivity was $0.12 \mathrm{ng} \mathrm{mL}^{-1}$ and the intra-assay coefficients of variation for low $\left(0.5 \mathrm{ng} \mathrm{mL}^{-1}\right)$, medium (2 $\left.\mathrm{ng} \mathrm{mL}^{-1}\right)$, and high $\left(8 \mathrm{ng} \mathrm{mL}^{-1}\right)$ controls were $3.5,2.6$, and $2.2 \%$, respectively.

Concentrations of insulin and metabolites were determined in samples from days $0,7,14,21$, and 28 . Glucose, total protein, albumin, urea, cholesterol, and NEFA concentrations were determined spectrophotometrically using commercial kits (Glucose Oxidase/Peroxidase, Biuret, Bromocresol Green; Urease/salicylate; Cholesterol Oxidase/Peroxidase, BioSystems SA, Barcelona, Spain, Wako NEFA-HR (2), Wako Pure Chemical Industries Ltd., Osaka, Japan, respectively), with a sample volume and reagents adjusted to 96 cells and read in a Multiskan EX (Thermo Scientific, Waltham, Massachusetts, USA). The intra and inter-assay coefficients of variation for the high and low controls were less than $15 \%$. Insulin concentration was determined by immunoradiometric assay (IRMA; Diasource, Brussels, Belgium). All samples were analyzed in one assay - the standard curve and controls in duplicate and the samples in single. The sensitivity of the assay was $1.1 \mathrm{uIU} \mathrm{mL} \mathrm{m}^{-1}$ and the intra-assay coefficients of variation for low $\left(24.7 \mathrm{uUI} \mathrm{mL} \mathrm{m}^{-1}\right)$ and high $\left(55.3 \mathrm{uIU} \mathrm{mL} \mathrm{mL}^{-1}\right)$ controls were 4.9 and $5.1 \%$, respectively.

The data were analyzed using SAS (Statistical Analysis System, version 9.2). The experiment was a completely randomized design and the individual cow was considered the experimental unit. Body condition score data were grouped in two different periods: monitoring phase (last third of gestation - beginning of supplementation) and experimental period (from the beginning of supplementation to the fixed-time artificial insemination). Data of milk production and composition, cow and calf weight, and concentrations of metabolites and insulin were analyzed using repeated measures analysis (MIXED procedure) with the date as the repeated factor. The following statistical model was applied:

$$
\text { Yijk }=\mu+\mathrm{c} 1+\mathrm{Ti}+\mathrm{Dj}+\mathrm{TDij}+\text { Eijk, }
$$

in which $\mu=$ overall mean; $\mathrm{c} 1=$ covariate with the initial value of the variable; $\mathrm{Ti}=$ effect of treatment; $\mathrm{Dj}=$ effect of date; TDij = effect of interaction between treatment and date; and Eijk = residual error. Treatment, date, and the interaction between the two factors were included as fixed effect, and animal as the random effect. The first measures were used as covariates in the respective analysis. Data of BW of calves included the effects of sex, and birth weights were used as covariates. When the main effect was significant, the differences among means were analyzed using the Tukey-Kramer test.

Reproductive variables were analyzed using generalized model (GENMOD procedure) specifying the binomial distribution with logit transformation of the data (anestrus and pregnancy) or Poisson distribution (interval calving-conception). The model included treatment effects:

$$
\mathrm{Yij}=\mu+\mathrm{Ti}+\mathrm{Eij} \text {, }
$$

in which: $\mu=$ overall mean; $\mathrm{Ti}=$ effect of treatment; and Eij $=$ residual error.

Correlation coefficients were estimated using the CORR procedure. Data were expressed as mean and standard error of the mean (Mean $\pm \mathrm{SEM}$ ) and considered statistically significant if $\mathrm{P}<0.05$.

\section{Results}

During the monitoring phase, the BCS of the cows decreased $(\mathrm{P}<0.001)$ from $16 \pm 1$ weeks pre-partum (early winter) to $47 \pm 1$ DPP. Cows lost an average of $1.5 \pm 0.1 \mathrm{BCS}$ units throughout this period, which corresponded to a loss of $1.2 \pm 0.1$ units in the last gestation and $0.3 \pm 0.1$ units in the postpartum period. The nadir of BCS was reached in the 4th week postpartum and remained low until the beginning of the supplementation period.

Supplementation did not influence the BCS (SUP: $3.9 \pm 0.1$ vs. $\mathrm{CON}: 3.9 \pm 0.1 ; \mathrm{P}=0.257)$, and no interaction was found between supplementation and date $(\mathrm{P}=0.540)$. Body weight was affected by supplementation $(\mathrm{P}=0.044)$. Cows from the SUP group were heavier than cows from the CON group (SUP: $379 \pm 2 \mathrm{~kg}$ vs. CON: $373 \pm 2 \mathrm{~kg}$; Table 2). Supplementation affected milk production $(\mathrm{P}=0.017)$. Cows of the SUP group $\left(5.7 \pm 0.2 \mathrm{~kg} \mathrm{~d}^{-1}\right)$ produced $14 \%$ more milk than the cows of the CON group $\left(5.0 \pm 0.2 \mathrm{~kg} \mathrm{~d}^{-1}\right)$. The supplementation vs. date interaction was significant $(\mathrm{P}=0.047$, Table 2). Supplementation affected the BW of calves $(\mathrm{P}<0.001)$, and a treatment vs. date interaction was found $(\mathrm{P}<0.001)$. The calves from dams of the SUP group were heavier from days 14 to 35 than calves from CON group (Table 2). From days 0 to 14 of supplementation, while calves were suckling, they gained $0.26 \pm 0.07 \mathrm{~kg} \mathrm{~d}^{-1}$ more than the calves from CON dams (CON: $0.48 \pm 0.07$ vs. SUP: $\left.0.74 \pm 0.07 \mathrm{~kg} \mathrm{~d}^{-1} ; \mathrm{P}=0.010\right)$. However, during 
Table 2 - Body condition score (BCS), body weight (BW), and milk production of primiparous cows and BW of the calves whose mothers were not supplemented $(\mathrm{CON})$ or supplemented for 21 days with whole rice bran and crude glycerin (SUP)

\begin{tabular}{|c|c|c|c|c|c|c|c|c|}
\hline & \multicolumn{2}{|c|}{ BCS (1-8 scale) } & \multicolumn{2}{|c|}{ Cow BW (kg) } & \multicolumn{2}{|c|}{$\operatorname{Milk}\left(\mathrm{kg} \mathrm{d}^{-1}\right)$} & \multicolumn{2}{|c|}{ Calf BW (kg) } \\
\hline & $\mathrm{CON}$ & SUP & $\mathrm{CON}$ & SUP & $\mathrm{CON}$ & SUP & $\mathrm{CON}$ & SUP \\
\hline 0 & $3.8 \pm 0.1$ & $3.8 \pm 0.1$ & $369 \pm 3$ & $372 \pm 3$ & $6.5 \pm 0.3$ & $6.9 \pm 0.3$ & $67 \pm 2$ & $67 \pm 2$ \\
\hline 14 & $3.8 \pm 0.1$ & $3.9 \pm 0.1$ & $373 \pm 3 b$ & $382 \pm 3 a$ & $6.8 \pm 0.3 b$ & $8.1 \pm 0.3 \mathrm{a}$ & $74 \pm 2 b$ & $78 \pm 2 \mathrm{a}$ \\
\hline 21 & $3.9 \pm 0.1$ & $3.9 \pm 0.1$ & $369 \pm 3$ & $374 \pm 3$ & $1.5 \pm 0.3$ & $1.3 \pm 0.3$ & $76 \pm 2 b$ & $80 \pm 2 a$ \\
\hline 35 & $4.0 \pm 0.1$ & $4.0 \pm 0.1$ & $381 \pm 3$ & $389 \pm 3$ & $5.1 \pm 0.3 b$ & $6.3 \pm 0.3 \mathrm{a}$ & $83 \pm 2 b$ & $88 \pm 2 a$ \\
\hline $139^{1}$ & & & & & & & $142 \pm 2 b$ & $150 \pm 2 \mathrm{a}$ \\
\hline
\end{tabular}

Day 0 - start of supplementation at $47 \pm 1$ days postpartum.

${ }^{1}$ Age at weaning: $186 \pm 1.4$ days of age.

Means with different letters within rows differ $(\mathrm{P}<0.05)$ (overall mean \pm standard error of the mean).

the temporary weaning with separation from their mothers, daily gain did not differ between groups $(\mathrm{P}=0.380)$, and was lower $(\mathrm{P}<0.001)$ than in the previous period $(0.20 \pm 0.05$ $\mathrm{kg} \mathrm{d}^{-1}$ for both groups). As expected, from days 0 to day 35 , a positive correlation was found between BW gain of the calves and milk production of their dams $(r=0.34$; $\mathrm{P}<0.001)$. At definitive weaning, calves from supplemented dams were on average $8 \mathrm{~kg}$ heavier $(\mathrm{P}=0.029)$ than calves from CON dams (Table 2).

The supplement did not affect the milk fat content, expressed as a percentage $(\mathrm{P}=0.225)$ or as the total content $(\mathrm{P}=0.794)$. No effect of date $(\mathrm{P}=0.127)$ or treatment vs. date interaction $(\mathrm{P}=0.178)$ was found. The average fat percentage and total content was $3.0 \pm 0.1 \%$ and $216 \pm 10 \mathrm{~g} \mathrm{~d}^{-1}$, respectively. On the contrary, supplementation increased $(\mathrm{P}<0.001)$ milk protein content $(\mathrm{CON}: 2.9 \pm 0.1$ vs. SUP: $3.1 \pm 0.1 \%)$, and a treatment vs. date interaction was found $(\mathrm{P}<0.001)$. In cows from the SUP group, the milk protein content increased from days 0 to $14(2.9 \pm 0.1$ to $3.3 \pm 0.1 \%$; $\mathrm{P}<0.001$ ), while in cows of the CON group, it remained unchanged ( $2.9 \pm 0.1$ to $2.9 \pm 0.1 \% ; \mathrm{P}=0.820$ ).

Supplementation did not affect plasma concentrations of total protein (SUP: $75.6 \pm 1.1$ vs. CON: $76.3 \pm 1.0 \mathrm{~g} \mathrm{~L}^{-1}$; $\mathrm{P}=0.627$ ), albumin (SUP: $33.0 \pm 0.6$ vs. CON: $32.6 \pm 0.6 \mathrm{~g} \mathrm{~L}^{-1}$; $\mathrm{P}=0.619$ ), or urea (SUP: $14.4 \pm 0.9$ vs. $\mathrm{CON}: 15.3 \pm 0.9 \mathrm{mg} \mathrm{dL}^{-1}$; $\mathrm{P}=0.486)$. There was also no effect of the supplementation vs. date interaction on albumin $(P=0.687$, Figure 1a) or total protein concentration $(\mathrm{P}=0.578$, Figure $1 \mathrm{c})$; however, the urea concentration was affected by this interaction ( $\mathrm{P}=0.036)$. One week after the beginning of supplementation (day 7), cows in the SUP group had lower urea values $(\mathrm{P}=0.012)$ than cows in the $\mathrm{CON}$ group, but these differences disappeared thereafter (Figure 1b).

Cows in the SUP group had higher plasma glucose concentrations than cows in the CON group (CON: 68.6 \pm 1.2 vs. SUP: $72.0 \pm 1.2 \mathrm{mg} \mathrm{dL}^{-1} ; \mathrm{P}=0.028$ ). Glucose concentration increased in SUP cows and differed $(\mathrm{P}=0.001)$ from $\mathrm{CON}$ cows on day 28 (Figure 1e). The plasma cholesterol concentration was higher $(\mathrm{P}=0.029)$ in SUP $\left(223.2 \pm 6.4 \mathrm{mg} \mathrm{dL}^{-1}\right)$ than in CON cows $\left(202.1 \pm 6.4 \mathrm{mg} \mathrm{dL}^{-1}\right)$, and on day 14 , SUP cows had the highest cholesterol concentration, differing from CON cows $(P=0.005$; Figure $1 \mathrm{~g})$. Supplementation decreased $(\mathrm{P}<0.001)$ the concentration of NEFA (SUP: $0.45 \pm 0.02$ vs. CON: $\left.0.56 \pm 0.02 \mathrm{mmol} \mathrm{L}^{-1}\right)$. The concentration of NEFA in the SUP cows decreased $(\mathrm{P}=0.017)$ and remained low from days 7 to 14 (Figure 1f).

Insulin concentration in SUP cows was higher $(\mathrm{P}=0.011)$ than in CON cows $\left(8.3 \pm 0.4\right.$ vs. $\left.7.0 \pm 0.3 \mathrm{uIU} \mathrm{mL}^{-1}\right)$. Insulin increased and was higher $(\mathrm{P}=0.004$; Figure $1 \mathrm{~d})$ than the CON cows in the first seven days of supplementation.

Independently of the BCS at calving, all cows were in deep anestrus when supplementation began. Twentyone days after the introduction of bulls (day 42 after the start of supplementation), $36 \%$ more cows of the SUP group were in shallow anestrus than cows of CON group (Table 3).

Table 3 - Percentage of primiparous cows not supplemented (CON) and supplemented for 21 days before mating with whole rice bran and crude glycerin (SUP), in shallow anestrus from the start of supplementation until 21 days of mating, pregnancy rates at 33 (early pregnancy), 43 (fixed-time artificial insemination pregnancy), and 74 (total pregnancy) days of mating, and calving - conception interval (days)

\begin{tabular}{lccc}
\hline & \multicolumn{3}{c}{ Nutritional treatment } \\
\cline { 2 - 4 } & CON & SUP & P-value \\
\hline Shallow anestrus & $21(3 / 14)$ & $57(8 / 14)$ & 0.049 \\
Early pregnancy & $7(1 / 14)$ & $7(1 / 14)$ & 0.998 \\
Fixed-time artificial insemination & $23(3 / 13)$ & $46(6 / 13)$ & 0.221 \\
pregnancy & & & \\
Total pregnancy & $64(9 / 14)$ & $79(11 / 14)$ & 0.401 \\
Calving-conception interval & $108 \pm 5$ & $110 \pm 5$ & 0.770 \\
\hline
\end{tabular}

Shallow anestrus was defined as the presence of follicles $>8 \mathrm{~mm}$ in the absence of corpus luteum in two or more ultrasound studies at 7-day intervals. Cows that were in anestrus in the first 33 days of mating entered the fixed-time artificial insemination program. Ten days after fixed-time artificial insemination, cows were naturally rebred for 21 days. The entire mating period lasted 74 days. Numbers in brackets represent number of cows. 



Day 0 - start of supplementation, at $47 \pm 1.4$ days postpartum.

Differences between treatments are indicated by * when $\mathrm{P}<0.05$.

Figure 1 - Concentrations of insulin and metabolites in primiparous cows non-supplemented ( $\mathbf{a})$ and supplemented for 21 days with whole rice bran and crude glycerin $(\square)$.

In the first 33 days of the mating period, only two cows - one of each group - were detected in estrus, and both became pregnant. The pregnancy rate after fixedtime artificial insemination in SUP cows was twice that of CON cows; however, this difference was not statistically significant (Table 3). After the second period with the bulls, more cows became pregnant $(8 / 17 ; 47 \%)$, and no differences between treatments were found $(\mathrm{P}=0.410)$. The final pregnancy rate was not different between groups. The type of anestrus on day 21 of the mating period influenced overall pregnancy rate $(\mathrm{P}=0.026)$. Indeed, more cows showing shallow anestrus became pregnant $(91 \% ; 10 / 11)$ compared with cows showing deep anestrus $(53 \% ; 9 / 17)$.
No clinical signs of methanol intoxication were observed during the supplementation period or one week after. Hepatic functionality, evaluated by the concentrations of total protein, albumin, globulin, total bilirubin, ASAT, ALP, and GGT performed on all the cows 110 days after the start of supplementation, showed no sign of hepatic damage.

\section{Discussion}

In extensive grassland cow-calf systems, the last third of pregnancy and early post-partum occurs during winter months, when forage availability and quality are lower 
than in fall or spring (Carámbula, 1991). Cows, in these conditions, show a negative energy balance and lose BCS (Soca et al., 2014a). As reported in other countries (Houghton et al., 1990; Perry et al., 1991; Stalker et al., 2006), and in our conditions (Quintans et al., 2010; Scarsi, 2012), in the present work, the loss of BCS was greater during prepartum than early postpartum. As a consequence, BCS at calving was lower than those recommended (4.5 units; scale of 1-8) to obtain a pregnancy probability similar to or greater than 70\% (Orcasberro et al., 1994).

The nadir of BCS was observed in the 4th week of the postpartum and remained low until supplementation began. The postpartum supplementation had no effect on BCS and stimulated only a transient increase in BW. The effect of the pre-mating supplementation on BCS is not consistent and seems to depend, at least partially, on the supplement used. Astessiano et al. (2013) and Soca et al. (2013) used a supplement based on whole rice bran and reported no effect on BCS. However, cows grazing on pasture improved with Lotus subbiflorus cv. Rincón, during the same period, increased BCS (Astessiano et al., 2012).

Supplementation increased milk production as has been reported previously in dairy (Reis and Combs, 2000; Bargo et al., 2002), dual purpose (Aguilar-Pérez et al., 2009), and beef cows (Perry et al., 1991; Lalman et al., 2000). The observed increase in milk protein content was also reported in dairy cows, and is attributed to a higher energy intake by cows supplemented with concentrates (Dillon et al., 1997; Reis and Combs, 2000; Bargo et al., 2002) and with crude glycerin (Bodarski et al., 2005). At the beginning of the supplementation, cows were in a physiological period $(47 \pm 1.4 \mathrm{DPP})$ in which the mammary gland is prioritized in the partitioning of nutrients (Bauman and Currie, 1980), so the supplement increased milk production and calf growth.

Neville (1962) suggested that during the first 60 DPP, milk production and weight gain of calves are linked, and as calves begin to consume grass, this ratio decreases. The increase in the availability of milk with greater protein content for calves from the SUP cows determined an increase in their daily weight gain. Calf daily weight gain decreased during the temporary weaning with separation from their mothers and increased again after calves returned with them. These findings give major support to the concept that the development of calves is milk-dependent up to 90 days of age (Grings et al., 2008; Quintans et al., 2010). The daily gains observed after temporary weaning with separation are in agreement with those reported by other authors (Beal et al., 1990). Calf daily gains during the evaluated period ( 0.54 and $0.60 \mathrm{~kg} \mathrm{~d}^{-1}, \mathrm{CON}$ and SUP groups, respectively) were similar to those reported by Quintans et al. (2010)
(0.65 $\left.\mathrm{kg} \mathrm{d}^{-1}\right)$, and Soca et al. (2014b) $\left(0.50 \mathrm{~kg} \mathrm{~d}^{-1}\right)$. These authors worked with multiparous and primiparous grazing cows, respectively, with similar BCS to those of the cows used in the present work. The greater BW shown by calves from SUP cows during the supplementation period remained until the final weaning, which is in agreement with the results reported by Astessiano (2010). These results show that short-term supplementation before mating increases the productivity of primiparous cows.

Beef heifers in anestrus show the highest NEFA plasma concentrations, which reflect their negative energy balance (Bossis et al., 2000). The frequency of LH pulses is negatively correlated with plasma concentration of NEFA in primiparous suckling beef cows (Grimard et al., 1995). In addition, an increase in NEFA plasma concentration could have a negative effect on the ovarian function (Bossis et al., 1999). In the present work, the plasmatic concentration of NEFA was different between treatments, and reflected a different adipose tissue rate of lipolysis (Lucy, 2003). These results suggest that SUP cows had a better energy balance than CON cows. Moreover, plasma cholesterol concentration was greater in SUP than in CON cows. The plasma cholesterol concentration increases in supplemented dairy cows as a consequence of an increase in energy intake (Cavestany et al., 2005). In summary, in the present work, the plasma concentrations of NEFA, cholesterol, and glucose suggest an improvement in the energy balance of SUP cows (Bossis et al., 1999; Lucy, 2003).

A high energy intake increases the size of the follicles and the number of large follicles (diameter $>10 \mathrm{~mm}$ ) in beef cows (Perry et al., 1991; Aguilar-Pérez et al., 2009) and dairy cows (Lucy et al., 1991). It is possible that nutrition has a direct effect on the ovary, rather than an indirect effect via the hypothalamic-pituitary axis (Khireddine et al., 1998). At the beginning of supplementation, all cows were in deep anestrus, but 21 days after the mating period had begun, more SUP cows were in shallow anestrus than CON cows. Taking into account that one of the most important criteria to classify anestrus is the size of the follicle (Wiltbank et al., 2002), it is conceivable that the extra energy consumed by SUP cows had a stimulatory effect on folliculogenesis. However, either because the temporary weaning with separation failed to stimulate LH pulsatility, or because the supplement did not reach the levels required for this event to occur, the cows remained in anestrus. There is a positive correlation between the concentration of insulin and the reproductive response (Sinclair, 2008) and between insulin concentration and size of follicles (Khireddine et al., 1998). Although the number of SUP cows that became pregnant doubled the number of cows in the CON group, this 
difference was not significant, possibly because of the low number of animals and the binomial nature of this variable. However, the better results obtained with cows in shallow than deep anestrus after fixed-time artificial insemination reinforces the positive effect of the supplement on the reproductive function (Khireddine et al., 1998). Considering that the cows were primiparous, it is possible to think that the energy partitioning followed the priorities described by Short et al. (1990), so after they achieved the maintenance requirements, milk production had the highest priority, followed by their own growth and reproduction activity had the last.

Cows of SUP group consumed $110 \mathrm{~g}$ of methanol d $\mathrm{d}^{-1}$ during 21 days. During this period, no clinical sings that could be associated with methanol intolerance were observed. Moreover, the concentrations of total protein and albumin during the entire monitored period did not differ between groups, reflecting that liver synthesis of protein seemed not to be affected. The study of liver function at 110 days after the beginning of supplementation did not show impaired liver function. These findings are in agreement with those reported by Winsco et al. (2011), who infused 0 to $210 \mathrm{~g}$ of methanol day ${ }^{-1}$ directly into the rumen of steers and did not observe adverse effects on intake, digestion, or ruminal fermentation. These authors suggested that cattle could tolerate methanol consumption that largely exceeds the current recommendation of the United States Pharmacopeia (150 ppm) or the European Pharmacopeia (2000 ppm). In agreement, Dasari (2007) and Elam et al. (2008) suggested that maximum recommended levels of methanol should be revised; an issue that requires further research.

\section{Conclusions}

In primiparous beef cows grazing native grass, premating supplementation with whole rice bran and crude glycerin with high content of methanol improves energy balance and increases milk yield and calf growth without showing signs of toxicity, with a slight effect on the reproductive activity.

\section{Acknowledgments}

To Andrés Pena and Nicolás Spinelli, for the analysis of crude glycerin; DILAVE, for the hepatic functional studies; Biogran, for providing the glycerin with which this work was conducted; and the staff of EEBR, in particular Oscar and José Cáceres, Dorrel Bentancour, and Ing. Agr. Carlos Mantero. Special thanks to Dr Carolina Viñoles, for the revision of the manuscript, and Dr. Pablo Speranza, for the language revision. Partially funded by CSIC (PAIE), Universidad de la República, Uruguay. L Román and JM Clariget were holders of scholarships from ANII, Uruguay.

\section{References}

Aguilar-Pérez, C.; Ku-Vera, J.; Centurión-Castro, F. and Garnsworthy, P. C. 2009. Energy balance, milk production and reproduction in grazing crossbred cows in the tropics with and without cereal supplementation. Livestock Science 122:227-233.

Alexander, J.; Benford, D.; Boobis, A.; Ceccatelli, S.; Cravedi, J. P.; Doerge, D.; Domenico, A.; Dogliotti, E.; Edler, L.; Farmer, P.; Filipic, M.; Fink-Gremmels, J.; Fürst, P.; Guerin, T.; Katrine Knutsen, H.; Machala, M.; Mutti, A.; Schlatter, J. and VanLeeuwen, R. 2010. Scientific opinion on the abiotic risks for public and animal health of glycerine as co-product from the biodiesel production from category 1 animal by-products (ABP) and vegetable oils. European Food Safety Authority 8:1-22.

AOAC - Association of Official Analytical Chemistry. 1980. Official methods of analysis. 13th ed. AOAC International, Washington, D.C., USA.

AOAC - Association of Official Analytical Chemistry. 1990. Official methods of analysis. 15th ed. AOAC International, Arlington, VA., USA.

AOAC - Association of Official Analytical Chemistry. 2007. Official methods of analysis. 18th ed. AOAC International, Washington, D.C., USA.

AOCS - American Oil Chemists' Society. 1973. Official methods and recommended practices. 64th ed. New Orleans, USA.

AOCS - American Oil Chemists' Society. 2009. Official methods and recommended practices. 100th ed. Florida, USA.

AOCS - American Oil Chemists' Society. 2012. Official methods and recommended practices. 103rd ed. California, USA.

Astessiano, A. L. 2010. Perfiles metabólicos, endócrinos y de expresión génica hepática asociados a cambios en el balance energético de vacas de carne primíparas en condiciones de pastoreo. Thesis (M.Sc.). Universidad de la República, Montevideo, Uruguay.

Astessiano, A. L.; Pérez-Clariget, R.; Quintans, G.; Soca, P. and Carriquiry, M. 2012. Effects of a short-term increase in the nutritional plane before the mating period on metabolic and endocrine parameters, hepatic gene expression and reproduction in primiparous beef cows on grazing conditions. Journal of Animal Physiology and Animal Nutrition 96:535-544.

Astessiano, A. L.; Pérez-Clariget, R.; Espasandín, A. C.; López-Mazz, C.; Soca, P. and Carriquiry, M. 2013. Metabolic, productive and reproductive responses to postpartum short-term supplementation in primiparous beef cows. Revista Brasileira de Zootecnia 42:246-253.

Bargo, F.; Muller, L. D.; Delahoy, J. E. and Cassidy, T. W. 2002. Milk response to concentrate supplementation of high producing dairy cows grazing at two pasture allowances. Journal of Dairy Science $85: 1777-1792$.

Bauman, D. E. and Currie, W. B. 1980. Partitioning of nutrients during pregnancy and lactation: a review of mechanisms involving homeostasis and homeorhesis. Journal of Dairy Science 63:1514-1529.

Beal, W. E.; Notter, D. R. and Akers, R. M. 1990. Techniques for estimation of milk yield in beef cows and relationships of milk yield to calf weight gain and postpartum reproduction. Journal of Animal Science 68:937-943.

Bell, A. W. 1995. Regulation of organic nutrient metabolism during transition from late pregnancy to early lactation. Journal of Animal Science 73:2804-2819. 
Bellows, R. A.; Short, R. E. and Richardson, G. V. 1982. Effects of sire, age of dam and gestation feed level on dystocia and postpartum reproduction. Journal of Animal Science 55:18-27.

Bodarski, R.; Wertelecki, T.; Bommer, F. and Gosiewski, S. 2005. The changes of metabolic status and lactation performance in dairy cows under feeding TMR with glycerine (glycerol) supplement at periparturient period. Journal of Polish Agricultural Universities $8: 1-9$.

Bossis, I.; Wettemann, R. P.; Welty, S. D.; Vizcarra, J. A.; Spicer, L. J. and Diskin, M. G. 1999. Nutritionally induced anovulation in beef heifers: ovarian and endocrine function preceding cessation of ovulation. Journal of Animal Science 77:1536-1546.

Bossis, I.; Wettemann, R. P.; Welty, S. D.; Vizcarra, J. and Spicer, L. J. 2000. Nutritionally induced anovulation in beef heifers: ovarian and endocrine function during realimentation and resumption of ovulation. Biology of Reproduction 62:1436-1444.

Carámbula, M. 1991. Aspectos relevantes para la producción de forraje. Instituto Nacional de Investigación Agropecuaria, Serie Técnica No. 19. Treinta y Tres, Uruguay.

Cavestany, D.; Blanc, J. E.; Kulcsar, M.; Uriarte, G.; Chilibroste, P.; Meikle, A. and Febel, H. 2005. Studies of the transition cow under a pasture-based milk production system: metabolic profiles. Journal Veterinary Medicine 52:1-7.

Ciccioli, N. H.; Wettemann, R. P.; Spicer, L. J.; Lents, C. A.; White, F. J. and Keisler, D. H. 2003. Influence of body condition at calving and postpartum nutrition on endocrine function and reproductive performance of primiparous beef cows. Journal of Animal Science 81:3107-3120.

Coppock, R. W. and Christian, R. G. 2012. Petroleum. p.745-778. In: Veterinary toxicology basic and clinical principles. 2nd ed. Gupta, R., ed. New York, USA.

Dasari, M. 2007. Crude glycerol potential described. Feedstuffs 79:1-3.

Dillon, P.; Crosse, S. and O'Brien, B. 1997. Effect of concentrate supplementation of grazing dairy cows in early lactation on milk production and milk processing quality. Journal of Agricultural and Food Research 36:145-159.

Donkin, S. S. 2008. Glycerol from biodiesel production: the new corn for dairy cattle. Revista Brasileira de Zootecnia 37:280-286.

Elam, N. A.; Eng, K. S.; Bechtel, B.; Harris, J. M. and Crocker, R. 2008. Glycerol from biodiesel production: considerations for feedlot diets. p.1-13. In: Proceedings of the Southwest Nutrition and Management Conference. Arizona, USA.

Griffin, P. G. and Ginther, O. J. 1992. Research applications of ultrasonic imaging in reproductive biology. Journal of Animal Science 70:953-972.

Grimard, B.; Humblot, P.; Ponter, A. A.; Mialot, J. P.; Sauvant, D. and Thibier, M. 1995. Influence of postpartum energy restriction on energy status, plasma LH and oestradiol secretion and follicular development in suckled beef cows. Journal of Reproduction and Fertility 104:173-179.

Grings, E. E.; Roberts, A. J.; Geary, T. W. and MacNeil, M. D. 2008. Milk yield of primiparous beef cows from three calving systems and varied weaning ages. Journal of Animal Science 86:768-779.

Haydock, K. P. and Shaw, N. H. 1975. The comparative yield method for estimating dry matter yield of pasture. Australian Journal of Experimental Agriculture and Animal Husbandry 15:663-670.

Hess, B. W.; Lake, S. L.; Scholljegerdes, E. J.; Weston, T. R.; Nayigihugu, V.; Molle, J. D. and Moss, G. E. 2005. Nutritional controls of beef cow reproduction. Journal of Animal Science 83:90-106.

Houghton, P. L.; Lemenager, R. P.; Horstman, A.; Hendrix, K. S. and Moss, G. E. 1990. Effects of body composition, pre and postpartum energy level and early weaning on reproductive performance of beef cows and preweaning calf gain. Journal of Animal Science 68:1438-1446.

Khireddine, B.; Grimard, B.; Ponter, A. A.; Ponsart, C.; Boudjenah, H.; Mialot, J. P.; Sauvant, D. and Humblot, P. 1998. Influence of flushing on LH secretion, follicular growth and the response to estrus synchronization treatment in suckled beef cows. Theriogenology 49:1409-1423.

Lalman, D. L.; Williams, J. E.; Hess, B. W.; Thomas, M. G. and Keisler, D. H. 2000. Effect of dietary energy on milk production and metabolic hormones in thin primiparous beef heifers. Journal of Animal Science 78:530-538.

Lucy, M. C. 2003. Mechanisms linking nutrition and reproduction in postpartum cows. Reproduction 61:237-254.

Lucy, M. C.; Staples, C. R.; Michel, F. M. and Thatcher, W. W. 1991. Energy balance and size and number of ovarian follicles detected by ultrasonography in early postpartum dairy cows. Journal of Dairy Science 74:473-482.

Meikle, A.; Kulcsar, M.; Chilliard, Y.; Febel, H.; Delavaud, C.; Cavestany, D. and Chilibroste, P. 2004. Effects of parity and body condition at parturition on endocrine and reproductive parameters of the cow. Reproduction 127:727-737.

Mondragon, I.; Wilton, J. W.; Allen, O. B. and Song, H. 1983. Stage of lactation effects, repeatabilities and influences on weaning weights of yield and composition of milk in beef cattle. Canadian Journal of Animal Science 63:751-761.

Mulliniks, J. T.; Kemp, M. E.; Cox, S. H.; Hawkins, D. E.; Cibils, A. F.; VanLeeuwen, D. M. and Petersen, M. K. 2011. The effect of increasing amount of glucogenic precursors on reproductive performance in young postpartum range cows. Journal of Animal Science 89:2932-2943.

Neville, W. E. 1962. Influence of dam's milk production and other factors on 120- and 240-day weight of Hereford calves. Journal of Animal Science 21:315-320.

NRC - National Research Council. 2001. The nutrient requirement of dairy cattle. 7 th ed. Washington, D.C., USA.

Orcasberro, R. 1994. Propuesta de manejo para mejorar la eficiencia reproductiva de los rodeos de cría. p.12-16. In: El mercado agropecuario. Montevideo, Uruguay.

Pérez-Clariget, R.; Carriquiry, M. and Soca, P. 2007. Estrategias de manejo nutricional para mejorar la reproducción en ganado bovino. Archivos Latinoamericanos de Producción Animal 15:114-119.

Perry, R. C.; Corah, L. R.; Cochran, R. C.; Beal, W. E.; Stevenson, J. S.; Minton, J. E.; Simms, D. D. and Brethour, J. R. 1991. Influence of dietary energy on follicular development, serum gonadotropins, and first postpartum ovulation in suckled beef cows. Journal of Animal Science 69:3762-3773.

Quintans, G.; Banchero, G.; Carriquiry, M.; López-Mazz, C. and Baldi, F. 2010. Effect of body condition and suckling restriction with and without presence of the calf on cow and calf performance. Animal Production Science 50:931-938.

Reis, R. B. and Combs, D. K. 2000. Effects of increasing levels of grain supplementation on rumen environment and lactation performance of dairy cows grazing grass-legume pasture. Journal of Dairy Science 83:2888-2898.

Scarsi, 2012. Efecto de una suplementación corta preparto en variables metabólicas, productivas y reproductivas en vacas multíparas y primíparas para carne. Thesis (M.Sc.). Universidad de la República, Montevideo, Uruguay.

Schröder, A. and Südekum, K. H. 1999. Glycerol as a by-product of biodiesel production in diets for ruminants. Paper No. 241. In: Proceedings of the 10th International Rapeseed Congress: New Horizons for an Old Crop. Canberra, Australia. Available at: $<\mathrm{http}$ //www.regional.org.au/au/gcirc/1/241.htm>. Accessed on: Mar. 4, 2014. 
Short, R. E.; Bellows, R. A.; Staigmiller, R. B.; Berardinelli, J. G. and Custer, E. E. 1990. Physiological mechanisms controlling anestrus and infertility in postpartum beef cattle. Journal of Animal Science 68:799-816.

Sinclair, K. D. 2008. Lactational anoestrus in cattle: lessons from the suckled beef cow. Cattle Practice 16:24-31.

Soca, P.; Carriquiry, M.; Claramunt, M.; Gestido, V. and Meikle, A. 2014a. Metabolic and endocrine profiles of primiparous beef cows grazing native grassland. 1. Relationship between body condition score at calving and metabolic profiles during the transition period. Animal Production Science 54:856-861.

Soca, P.; Carriquiry, M.; Claramunt, M.; Ruprechter, G. and Meikle, A. 2014b. Metabolic and endocrine profiles of primiparous beef cows grazing native grassland. 2. Effects of body condition score at calving, type of suckling restriction and flushing on plasmatic and productive parameters. Animal Production Science 54:862-868.

Soca, P.; Carriquiry, M.; Keisler, D. H.; Claramunt, M.; Do Carmo, M.; Olivera-Muzante, J.; Rodríguez, M. and Meikle, A. 2013. Reproductive and productive response to suckling restriction and dietary flushing in primiparous grazing beef cows. Animal Production Science 53:283-291.

Soca, P.; Claramunt, M. and Do Carmo, M. 2007. Sistemas de cría vacuna en ganadería pastoril sobre campo nativo sin subsidios: propuesta tecnológica para estabilizar la producción de terneros con intervenciones de bajo costo y de fácil implementación. Revista Ciencia Animal 3:3-22.
Stalker, L. A.; Adams, D. C.; Klopfenstein, T. J.; Feuz, D. M. and Funston, R. N. 2006. Effects of pre and postpartum nutrition on reproduction in spring calving cows and calf feedlot performance. Journal of Animal Science 84:2582-2589.

Van Soest, P. J.; Robertson, J. B. and Lewis, B. 1991. Methods for dietary fiber, neutral detergent fiber, and nonstarch polysaccharides in relation to animal nutrition. Journal Dairy Science 74:3583-3597.

Vizcarra, J. A.; Ibañez, W. and Orcasberro, R. 1986. Repetibilidad y reproductividad de dos escalas para estimar la condición corporal de vacas Hereford. Investigaciones Agronómicas 7:45-47.

Wang, Y.; Xin, H. S.; Li, Y.Z.; Zhang, W. W.; Xia, K.; Wang, Z. B.; Li, M. and Zhang, Y. G. 2012. The effects of different processing methods on the estimated nutritional value of rice bran according to NRC-2001 Model or DVE/OEB System. Journal of Animal and Feed Sciences 21:503-520.

Williams, G. L. 1990. Suckling as a regulator of postpartum rebreeding in cattle: a review. Journal of Animal Science 68:831-852.

Wiltbank, J. N. 1970. Research needs in beef cattle reproduction. Journal of Animal Science 31:755-762.

Wiltbank, M. C.; Gumen, A. and Sartori, R. 2002. Phisiological clasiffication of anovullatory conditions in cattle. Theriogenology 57:21-52.

Winsco, K. N.; Kenney, N. M.; Dittmar, R. O.; Coverdale, J. A.; Sawyer, J. E. and Wickersham, T. A. 2011. Effect of methanol infusion on intake and digestion of a grain-based diet by beef cattle. p.120-121. In: Proceeding of the Plains Nutrition Council Spring Conference. Texas, USA. 